\title{
DIREITO E SOCIEDADE NA AMAZÔNIA: SOBRE A PROIBIÇÃO LEGAL DO USO DO FOGO EM ATIVIDADES ECONÔMICAS AGROPASTORIS
}

David Wilson de Abreu Pardo

LAW AND SOCIETY IN THE AMAZON: THE LEGAL PROHIBITION ON THE USE OF FIRE IN AGRO-PASTORAL ECONOMIC ACTIVITIES

\section{RESUMO}

ANÁLISE DE CONFLITO SOCIOAMBIENTAL CAUSADO PELO USO DO FOGO EM ATIVIDADES ECONÔMICAS AGROPASTORIS NA AMAZÔNIA, COM O OBJETIVO DE OFERECER TRATAMENTO JURÍDICO PARA A PROBLEMÁTICA, CONSTRUINDO O ARGUMENTO A PARTIR DO NIVEEL DA LEI E PASSANDO AO NÍVEL DOS DIREITOS E DA CONSTITUICÃO, INSERINDO NESTE OS TEMAS DA ECONOMIA E DA CULTURA. PROCEDIMENTO DE ANÁLISE E TRATAMENTO DOS ARGUMENTOS E INTERESSES DOS ATORES TAIS QUAIS RECONSTRUIDDOS, SUGERINDO A RESOLUCC̃O DO PONTO DE VISTA DO DIREITO COMO PRÁTICA SOCIAL, COM ENFOQUE CRÍTICO E CONTEXTUALIZADO DISCUSSÃO DO PROBLEMA ILUSTRADA COM DADOS DE UM PROCESSO DE AÇÃO CIVIL PÚBLICA PROPOSTA PELO MINISTÉRIO Público no Acre. Plano de trabalho com descrição INICIAL dO PROBLEMA DAS QUEIMADAS NA AMAZÔNIA. DepoIS, REFLEXÃO SOBRE O SENTIDO DA LEI FLORESTAL E REGULACÃO ADMINISTRATIVA DA PRÁtICA. FInALMENTE, eXAME DO ARGUMENTO CONSTITUCIONAL, REFUTANDO CONTESTACÕES DA ECONOMIA E DA CULTURA. CONCLUSÃo PELA CESSAÇÃO DAS QUEIMADAS COMO TÉCNICA DE PRODUC̄̃̃ ECONÔMICA NA AMAZÔNIA, EXCETUANDO O USO RESTRITO E CONTROLADO DO FOGO NA AGRICULTURA DE SUBSISTÊNCIA PRATICADO POR POPULACÕES TRADICIONAIS E INDÍGENAS.

PALAVRAS-CHAVE

Amazônia; Direito e sociedade; Uso do fogo.

\begin{abstract}
ANALYSIS OF ENVIRONMENTAL CONFLICT CAUSED BY THE USE OF FIRE IN AGROPASTORAL ECONOMIC ACTIVITIES IN THE AMAZON. PURPOSE OF PROVIDING LEGAL TREATMENT FOR THE PROBLEM, BUILDING THE ARGUMENT FROM THE LEVEL OF THE LAW AND PASSING THE LEVEL OF RIGHTS AND THE CONSTITUTION BY INSERTING IN THE THEMES OF ECONOMY AND CULTURE. PROCEDURE FOR ANALYSIS AND PROCESSING OF ARGUMENTS AND INTERESTS OF ACTORS, SUCH AS THEY REBUILT, SUGGESTING THE RESOLUTION OF THE POINT OF VIEW OF LAW AS A SOCIAL PRACTICE, FOCUSING ON CRITICAL AND CONTEXTUALIZED. DISCUSSION OF THE PROBLEM ILLUSTRATED WITH DATA FROM A PROCESS OF PUBLIC CIVIL ACTION FILED BY PROSECUTORS IN ACRE. WORK PLAN WITH THE INITIAL DESCRIPTION OF THE PROBLEM OF FIRES IN THE AMAZON. THEN REFLECT ON THE MEANING OF THE FORESTRY LAW AND ADMINISTRATIVE REGULATION OF THE PRACTICE. Finally, EXAMINATION OF THE CONSTITUTIONAL ARGUMENT, REFUTING CHALLENGES OF ECONOMY AND CULTURE. CONCLUSION BY THE CESSATION OF BURNING AS A TECHNIQUE OF ECONOMIC PRODUCTION IN THE AMAZON, EXCEPT RESTRICTED AND CONTROLLED USE OF FIRE IN SUBSISTENCE AGRICULTURE PRACTICED BY TRADITIONAL AND INDIGENOUS POPULATIONS.
\end{abstract}

\section{KEYWORDS}

AMAZON; LAW AND SOCIETY; USE OF FIRE.

\section{INTRODUÇÃO}

Ano após ano, ao final do período de estiagem, a Amazônia se prepara para mergulhar em chamas e ser sufocada pelas densas fumaças expelidas durante a combustão das matas. Resultado do uso do fogo em atividades econômicas agropastoris ou florestais, 
que se perpetua ao longo do tempo na região. Nos verões, os produtores rurais realizam queimadas para limpeza e preparo da terra, com o objetivo de torná-la cultivável. Esse é o método mais disseminado, e barato, nas atividades agropastoris, adotado pelos diversos setores produtivos rurais. Sua aceitação remonta a tempos antigos. Nos últimos anos, porém, em virtude de graves incidentes decorrentes das queimadas no meio da floresta, surgiu um debate público acalorado dessa prática, já pesquisada em círculos mais restritos da agronomia e das ciências ambientais. Os impactos negativos cada vez mais crescentes causaram a indignação social e a exigência pública pelo fim da ação. No Acre, por exemplo, a mobilização social conduziu o Ministério Público a ingressar em Juízo com ação civil pública, ${ }^{1}$ visando a fazer cessar em definitivo a autorização para a queima controlada na região, requerida pelos produtores rurais locais.

A ação judicial apenas condensa em foro específico um conflito já existente e em curso na sociedade, com o envolvimento de diversos atores movidos por interesses diversos. De um lado, alega-se que a utilização do fogo na floresta acarreta prejuízos ao meio ambiente, à saúde, à segurança, à educação e à economia, tais como: redução do volume dos cursos d'água, emissão de gases tóxicos e partículas poluentes na atmosfera, supressão da biodiversidade florística e faunística; elevação da incidência de doenças respiratórias; redução da visibilidade, que compromete o tráfego aéreo e rodoviário. Também se diz que alguns fatores impossibilitariam o controle das queimadas e dos focos de incêndio, mormente se consideradas a elevação global da temperatura e a supressão progressiva da vegetação primária e, ainda, a inexistência de estrutura institucional adequada.

De outro lado, alega-se que a produção de alimentos na região está assentada no modelo tradicional de queima e pousio. O modelo é mantido há tempos e sua troca deve ser antecedida da disponibilidade de tecnologias sustentáveis de produção rural, munindo previamente os produtores dos mecanismos, sob pena de imprimir, por sentença ou decreto, uma significativa alteração no modo de vida dos indivíduos que integram a sociedade, para além dos espaços de discussão democrática. Em contrapartida, o possível o controle dos focos de incêndio, por meio de monitoramento, por sensoriamento remoto, dos licenciamentos concedidos, georreferenciados pelas instituições públicas.

Dado o contexto problemático, é possível empreender uma análise do conflito do ponto de vista do direito, obviamente sem prejuízo de avaliações a partir de outras perspectivas. O propósito seria sugerir um tratamento jurídico, desenvolver um argumento a partir do nível da lei e passando ao nível dos direitos e da Constituição, inserindo neste os temas da economia e da cultura, além de análise e tratamento, levando em conta os argumentos e interesses dos atores, tais quais reconstruídos, e propor uma resolução baseada nos direitos. A questão mais geral a guiar a discussão tem a seguinte estrutura: as peculiaridades atuais da Amazônia justificam o uso do 
fogo em práticas agropastoris ou florestais visando ao incremento da renda e ao desenvolvimento regional?

Tem sua importância investigar, a partir do direito, região estratégica para o Brasil, e em destaque no cenário internacional, que ainda não está recebendo atenção suficiente nos debates jurídicos nacionais acerca do desenvolvimento econômico, social e das questões relativas ao desenvolvimento sustentável. Em perspectiva interdisciplinar apropriada para uma investigação que não pretende, e nem teria como, dada a complexidade do tema, ficar reduzida a uma análise de enunciados legais, a resposta ao problema será construída do ponto de vista do direito como prática social, com enfoque crítico e contextualizado. Não se abordará, contudo, o fato de a cessação do uso fogo na produção agropastoril poder ser buscada pela via judicial, o que resultaria em discussões importantes sobre os limites institucionais do Judiciário na execução de políticas públicas. Esse debate será feito com exclusividade em outro artigo.

Por enquanto, o propósito é avançar um tratamento jurídico para o conflito, do ponto de vista estrito da justiça. Para isso, em primeiro lugar, será feita uma descrição do problema das queimadas na Amazônia (1), com a identificação dos atores do conflito e seus interesses divergentes. Depois, a reflexão será sobre o sentido da lei, na aplicação específica à situação problemática (2), destacando-se o debate a respeito da intervenção do direito na Administração Pública. Em seguida, avaliaremos o argumento constitucional (3), para reforçar a conclusão em favor da proibição legal das queimadas na região. No nível da Constituição, serão debatidos os argumentos da economia e da cultura. Pelo primeiro, não pode haver imediata intervenção do direito, enquanto não houver uma nova combinação de fatores de produção otimizando a renda e dispensando o uso do fogo. De acordo com o segundo, não se pode, por decreto, realizar uma alteração significativa no modo de vida dos indivíduos produtores. Este exibe outra dimensão, relativa à exceção da agricultura de subsistência praticada por populações tradicionais e indígenas.

O estudo do processo de ação civil pública protagonizada pelo Ministério Público no Acre foi relevante para o desenvolvimento da pesquisa, por condensar informações sobre os diversos aspectos do conflito que, de outra forma, poderiam passar despercebidos. Claro que um processo reproduz e leva adiante o conflito social fazendo um recorte geográfico específico, que não alcança todas as nuances de um espaço tão gigantesco quanto a Amazônia brasileira. Mesmo assim, seus dados podem ser utilizados como exemplos para discutir o problema em caráter de maior generalidade. É o que se buscou fazer na presente investigação.

\section{O PROBlema dAS QUEIMAdAs nA Amazônia}

O uso do fogo em atividades agropastoris na Amazônia acarreta um tipo de conflito socioambiental em torno dos impactos gerados por esse tipo de ação humana, 
conforme a tipologia da literatura especializada (LITTLE, 2001). A disputa entre os grupos sociais, no caso, decorre dos impactos negativos da ação tanto para o funcionamento da natureza em si quanto para os seres humanos, pois contamina o meio ambiente e leva ao esgotamento dos recursos naturais e à degradação de ecossistemas. Na seção inicial, convém descrever a ação e seus impactos e identificar os principais atores do conflito e respectivos interesses, para uma posterior análise e tratamento à luz do direito.

A prática de queima e pousio consiste em desmatar uma área e, posteriormente, deixá-la em pousio, na forma de capoeiras, como estratégia de regeneração da vegetação, a fim de que possa ser utilizada novamente em atividades agrícolas, anos depois do desmate e da queima iniciais. Característica da agricultura brasileira, esse costume tem origem na compreensão intuitiva, oriunda dos povos indígenas, de que a terra tem um ciclo produtivo estanque, após o qual suas forças se exaurem; a utilização do fogo seria catalisadora da fertilidade do solo, caracterizando a chamada agricultura itinerante.

Os efeitos imediatos da queima potencializam a fertilidade: as cinzas provenientes da incineração de biomassa agregam-se ao solo, fornecendo-lhe matéria orgânica e elevando seu potencial de hidrogenação (pH) (SCHMITZ, 2007). Tratase de um método de eliminação dos resíduos orgânicos decorrentes da limpeza prévia da área e concomitante fertilização do solo, que propiciam maior produtividade, sobretudo nas culturas rotativas (arroz, milho, etc.), além de ter baixo custo para o produtor rural.

O problema é que a terra submetida a esse processo físico-químico extenua-se em período curto, uma vez que os nutrientes agregados ao solo se depositam em camadas superficiais, além da perda natural de nitrogênio durante a combustão. Isso exige a expansão da área cultivada, mediante novo processo de derrubada e queima, e inutilização temporária, mas prolongada, daquela anteriormente manejada, redundando em exploração agrícola extensiva cujos efeitos são a supressão da vegetação primária - e todos os efeitos decorrentes disso, como a supressão da biodiversidade faunística e florística - e a emissão sazonal de grande volume de gases tóxicos e micropartículas poluentes na atmosfera.

Outro aspecto problemático se destaca. Ainda que tenha sido herdada, essa prática dos povos indígenas, como ela é exercida atualmente pelos produtores rurais (de grande, médio ou pequeno porte), não carrega a antiga compreensão originária em sua relação com a terra e com a propriedade - agricultura de subsistência e nomadismo. A ótica dos produtores rurais é a do primado da exploração econômica dos recursos naturais, como a criação generalizada de animais de médio e grande portes.

Um dos grupos sociais que recebe os benefícios diretos da ação é constituído de produtores agropastoris que visam ao incremento da renda e ao desenvolvimento 
econômico regional. Aliás, a análise crítica do conflito à luz do direito terá em conta essencialmente esse grupo social. Ao longo do texto, a ação do grupo também é referida como o uso do fogo em atividades econômicas agropastoris ou florestais, diferenciando-o do uso na agricultura de subsistência pelas populações tradicionais e indígenas, a ser examinado mais ao final deste texto.

De outra banda, o reconhecimento de que se trata de uma prática agropastoril integrada a um peculiar modo de cultivo fincado na ancestralidade indígena impôs o beneplácito do Estado diante dessa forma de proceder, desde que adotadas certas precauções, na tentativa de delimitar as áreas a serem queimadas - o que se convencionou chamar de "queima controlada".

Há muito tempo, porém, as queimadas autorizadas pelo Estado vão muito além de sua origem silvícola, constituindo uma prática disseminada em toda a região para a produção agropastoril ou florestal para incrementar a renda e o desenvolvimento. Nisso reside o interesse do Estado, que aparece como ator importante do conflito e, em consequência lhe é imputada uma responsabilidade destacada pelos impactos negativos da prática.

A generalização do uso do fogo e a excessiva antropização do meio rural na Amazônia, com a abertura de grandes clarões na floresta primitiva, têm propiciado uma expansão indiscriminada dos focos de calor. As queimadas podem gerar incêndios devastadores em grandes áreas de mata nativa, os quais fogem totalmente ao controle.

O Estado sabe desse risco permanente e é cobrado a negar autorizações para "queimas controladas". Por exemplo, em memorando juntado ao processo de ação civil pública no Acre, o Instituto Brasileiro de Meio Ambiente reconheceu não haver esforços humanos capazes de conter o avanço dos incêndios sobre os ambientes antrópicos ou naturais e, além disso, que cenários futuros indicam maior frequência de repetição de incêndios descontrolados. ${ }^{2}$ No fundo, afigura-se difícil ou impossível o controle estatal de uma atividade que se distancia de sua origem, ameaça recursos naturais, degrada ecossistemas e afeta a saúde das pessoas.

Na verdade, a vegetação da Amazônia, ou pelo menos uma porção, ao contrário do que se pensava, perde parte da folhagem no período seco. Na região, predomina ainda certos tipos de vegetação (p.ex., bambu ou taboca) cuja unidade ocupa extensas áreas e, ao morrer, expõe-nas à insolação e ressecamento. Em conjunto, isso pode facilitar a expansão natural dos incêndios tópicos, ainda que realizados de acordo com as especificações definidas no ato de autorização para queima controlada. É o que relata pesquisador do Instituto Nacional de Pesquisas da Amazônia e do Parque Zoobotânico da Universidade Federal do Acre, em entrevista veiculada na rede mundial de computadores (FERREIRA, 2008): ${ }^{3}$

(...) essas florestas são verdadeiras bombas prontas para queimar de forma ainda mais dramática em caso de seca similar à de 2005 [porque] a morte 
do bambu provoca o aumento da insolação que atinge o chão da floresta, provocando a dessecação do solo e afetando, indiretamente, especialmente, as grandes árvores, que, sob estresse hídrico, tendem a perder folhas como forma de proteção contra a falta de água (...) [e] segundo o Manual Técnico da Vegetação Brasileira, do IBGE, (...) as florestas do Acre se encaixam na classificação Floresta Estacional Semidecidual ou, numa denominação mais antiga, em Floresta Tropical Subcaducifólia. (...) a palavra "semidecidual" se refere ao fato de que um grande número de árvores, o dossel da floresta, se comporta como espécies caducifólias, ou seja, que perdem totalmente as folhas durante o período mais seco do ano. A palavra "estacional" se refere ao fato de que estas florestas se localizam em regiões onde o período seco mais acentuado pode durar entre quatro e seis meses, o que vem a ser o caso do leste do Acre.

O risco de incêndios descontrolados na Amazônia devido às queimas autorizadas é sério e permanente. É justamente no final da estação seca, quando as queimas autorizadas são realizadas, as florestas, os campos e os plantios de culturas perenes estão mais suscetíveis ao poder devastador do fogo (MOTTA E OUTROS, 2002). Do risco à ocorrência efetiva dos incidentes é apenas um pequeno passo. Os incêndios devastam a regiões, que mergulham na fumaça e nas chamas mortais diante de um Estado e de uma sociedade impotentes. Essa realidade nefasta da prática para o funcionamento da natureza e para os seres humanos pode ser bem provada com uma rápida referência a um evento histórico recente na Amazônia Ocidental brasileira.

\section{I INCÊNDIOS NA FLORESTA ACRIANA EM 2005}

A conjunção da característica da vegetação acriana, da expansão da prática de queimadas e da drástica redução do índice pluviométrico (seca) no período em que há maior incidência de queimadas - agosto a outubro - deflagraram um desastre que assumiu proporções catastróficas em 2005. Houve propagação de incêndios em vastas extensões de florestas, significativa perda de biomassa, prejuízos à segurança (redução da visibilidade nos tráfegos aéreo e rodoviário), à saúde e às lavouras mantidas pelos próprios produtores rurais, além do acúmulo de resíduos que serão revertidos em gás carbônico ao longo de décadas.

Os impactos para os seres humanos foram realmente devastadores. Naquela ocasião, o Sistema Nacional de Defesa Civil (Sindec) estimou em R\$ 27.684.550 os prejuízos decorrentes dos incêndios ocorridos apenas no município de Rio Branco, Capital do Estado do Acre, que incluíam danos materiais, ambientais, econômicos e sociais. Foram afetadas direta ou indiretamente aproximadamente 24.253 pessoas, 12.464 das quais foram acometidas por enfermidades. Foram registradas oito mortes, em decorrência da poluição atmosférica. O nível de fumaça atingiu o patamar de 
$500 \mu \mathrm{g}$ por metro cúbico, superando, em muito, o nível máximo de conforto e o indicativo de estado de alerta (150 e $420 \mu \mathrm{g}$, respectivamente). ${ }^{4}$

Os impactos afetaram a saúde das pessoas, esgotaram os recursos naturais e degradaram ecossistemas. De acordo com Irving Foster Brown e Sumaia Saldanha de Vasconcelos, pesquisadores da Universidade Federal do Acre, em artigo publicado no jornal acriano Página 20: "em 2005, durante o pico das queimadas, era tanta fumaça que a visibilidade num dia não ultrapassava os 400 metros". ${ }^{5}$ Apresentamos uma breve descrição do que aconteceu:

Durante o período seco prolongado de 2005, parte das queimadas causadas por fogos propositais fugiu do controle e tornaram-se incêndios que destruíram ou danificaram dezenas de milhares de hectares de florestas e pastagens, além de cultivos agrícolas, cercas, currais, entre outros. Estimativas feitas para o leste do Acre por Wilfrid Schroeder (doutorando brasileiro na Universidade de Maryland), usando imagens de satélite obtidas antes do fim de setembro, indicam que foram queimados mais de $200 \mathrm{mil}$ hectares de áreas abertas (pastos e áreas agrícolas). De acordo com cálculos da Defesa Civil Estadual, as queimadas de 2005 geraram prejuízos na ordem de mais de cem milhões de reais, baseados nos custos diretos (pasto perdido, cercas e casas queimadas, produção agrícola queimada, etc.).

Evidências e informações indicam que há um risco permanente de expansão natural dos incêndios tópicos, ainda que realizados de acordo com as especificações definidas no ato estatal de autorização para queima controlada. Um comunicado técnico da Empresa Brasileira de Pesquisa Agropecuária de 2006 analisou o cenário da Amazônia em 2005 e conclui que, de 2005 a 2006, tinha havido um aumento significativo no número de pontos de queimadas no Estado do Acre (424\%), seguido pelos estados do Amazonas (168\%), Maranhão (36\%) e Rondônia (35\%). Apontou, ainda, que a concentração espacial do aumento das queimadas estava vinculada a diversas frentes de povoamento e colonização, à ampliação de pastagens e à atividade de exploração madeireira (MIRANDA E OUTROS, 2006).

A Floresta Amazônica, até então considerada foco de captura do carbono emitido pelos polos industriais e metropolitanos, passou a ser fonte de produção de gás carbônico para a atmosfera. Para agravar a situação, a perpetuação da prática da queimada acumula material combustível e destrói ainda mais a floresta. Trata-se de um fenômeno ambivalente: a redução do sequestro de carbono pelo decréscimo de vegetação viva, e a potencialização dos riscos de propagação de incêndios, com a emissão de maior quantidade de gás carbônico.

Além dos vultosos danos decorrentes da manutenção da prática, portanto, há possibilidade de reincidência do desastre ocorrido em 2005, culminando, quiçá, na 
supressão da vegetação primária na região. Dependendo da proporção do evento, o controle dos focos de incêndio, seja por meio de monitoramento, sensoriamento remoto ou licenciamentos concedidos e georreferenciados é pouco provável.

Alguns dos atores sociais envolvidos e seus interesses podem ser enumerados. De um lado, os produtores rurais, que executam a ação impactante, interessados no incremento da renda, alegam não haver uma tecnologia substitutiva. Estes têm o endosso do Estado, que continua a autorizar a prática, com a mesma alegação e interesse em promover o desenvolvimento regional. De outro lado, estão todos que sofrem diretamente com as queimadas.

\section{I.2 Alternativas ao uso do fogo}

Como um conjunto indeterminado de pessoas é afetado pelos impactos negativos da ação, o interesse na resolução do problema é difuso: um campo aberto para o surgimento de atores mais específicos no desenvolvimento do conflito. Por exemplo, no caso do incidente ocorrido no Acre, por iniciativa do Ministério Público, em ação civil pública, houve o deslocamento da questão para a esfera do Poder Judiciário. As alegações do MP para a intervenção foram: os efeitos danosos da prática podem ser evitados com o manejo de métodos alternativos, sem utilização do fogo na agricultura e com a otimização da exploração em áreas já degradadas pela lavoura itinerante, o que reduziria a expansão das áreas cultiváveis. O MP apontou estudos que indicam ao menos quatro alternativas para substituir o uso do fogo nas práticas agropastoris e florestais, permitindo a recuperação e conservação de solos alterados ou degradados pela sistemática queima:

a) Adubação orgânica: para utilização em leguminosas (como a mucuna-preta), que permite a redução do período de pousio para três anos, em vez de cinco anos exigidos pela capoeira, uma vez que proporciona cobertura do solo, fornece nitrogênio e matéria orgânica, e permite a emergência de nutrientes de profundas camadas do solo, o que reduziria o impacto das precipitações sobre a superfície do solo e minimizaria os efeitos da erosão e da lixiviação edáfica, ${ }^{6}$ com baixo custo aos produtores rurais.

b) Adubação química: embora tenha um custo elevado, exija análise prévia da composição do solo e ofereça riscos de contaminação de mananciais, a correta utilização possibilita a adequação do solo às necessidades da cultura que se pretende implantar e permite semeadura imediata.

c) Mecanização agrícola: possibilita o preparo da área sem utilização do fogo, promove a descompactação do solo e a construção de terraços em nível ou desnível, permite a constituição dos sistemas radiculares e melhor aproveitamento dos recursos hídricos, além disso, evita a lixiviação e a falta de germinação. 
d) Sistemas agroflorestais ou silvipastoris: consiste em consórcios rotativos ou não de pastagem com o plantio de árvores ou leguminosas e de culturas com exigências nutricionais diferentes que, além de melhorarem o solo (com porosidade, infiltração e nutrientes), o recompõe e conserva. Outras vantagens: diversificam as fontes de renda do produtor e reduzem a pressão sobre áreas ainda não cultivadas.

A adoção de um desses métodos permitiria a recomposição das áreas alteradas ou degradadas, a utilização racional dos recursos naturais, a cessação dos efeitos decorrentes do emprego do fogo (emissão de poluentes, probabilidade de expansão descontrolada dos focos de incêndio, supressão da vegetação primária, redução da capacidade de captura de gás carbônico, etc.), e a preservação da vegetação nativa. Há outros estudos descrevem alternativas semelhantes (MESQUITA, s.d.).

Assim descrito e contextualizado o conflito, é possível empreendermos uma análise do ponto de vista do direito. Como dito, nosso propósito é sugerir um tratamento jurídico para o problema, desenvolver um argumento a partir do nível da lei e passar ao nível dos direitos e da Constituição, inserindo neste os temas da economia e da cultura. As matizações serão feitas ao longo da resposta.

\section{A lei florestal e A Regulação das QUEIMAdAS}

A queima dita controlada tinha amparo legal no artigo 27, § único, do Código Florestal anterior (Lei n. 4.771/1965), que, ao proibir a utilização do fogo, ressalvava a possibilidade de permissão, pelo Poder Público, da sua utilização, em virtude de as peculiaridades locais justificarem esse emprego, devendo circunscrever as áreas e estabelecer normas de precaução. O capítulo II do Decreto n. 2.661/98 tratava da permissão do emprego do fogo, dispondo, no artigo $2^{\circ}$, que tal prática deveria ser feita mediante queima controlada, a depender (art. $3^{\circ}$ ), como ali se prescrevia, de autorização prévia.

O Decreto n. 2.661/98, para falar com precisão, regulamentava a permissão conferida pelo antigo Código Florestal, estabelecendo, nos dispositivos subsequentes, os critérios para a obtenção do beneplácito administrativo pelos produtores rurais, e definindo a inserção de condições e especificações técnicas adicionais a integrar o ato administrativo. É de se dizer: a prática de utilização do fogo era proibida, nos termos do artigo 27, caput, do antigo Código Florestal, ressalvando-se a realização de queima controlada, se peculiaridades locais ou regionais justificassem seu emprego em práticas agropastoris ou florestais.

O novo Código Florestal (Lei n. 12.651/2012), no caput do artigo 38, continua proibindo o uso de fogo na vegetação, excetuando, porém, os locais ou regiões cujas peculiaridades justifiquem seu uso em práticas agropastoris ou florestais, mediante prévia aprovação do órgão estadual ambiental competente do Sistema Nacional do 
Meio Ambiente, para cada imóvel rural ou de forma regionalizada, sendo que aquele órgão estabelecerá os critérios de monitoramento e controle (inciso I). $\mathrm{O} \S 2^{\circ}$ do referido artigo introduz ainda exceção relevante e inédita, em um texto legal, relativa às práticas de agricultura de subsistência exercidas pelas populações tradicionais e indígenas.

A abordagem central de nosso texto se atém à exceção do caput do artigo da nova lei, tomando como ponto de partida sua aplicação à atividade exercida por produtores rurais que avulta o primado da exploração econômica dos recursos naturais visando à geração de renda e ao desenvolvimento regional. Na seção que trata de cultura, será ressalvada a questão da agricultura de subsistência praticada por populações tradicionais e indígenas. Por ora, basta dizer que tais práticas são distintas. Se a exceção do caput já se aplicasse ao caso da agricultura de subsistência de populações específicas, não faria sentido algum incluir o $\S 2^{\circ}$ no artigo 38 da nova lei.

No nível da lei, importa perceber que a exceção à proibição, baseada na situação de locais ou regiões cujas peculiaridades justifiquem o emprego do fogo em práticas agropastoris ou florestais, reclama chancela oficial que não consubstancia uma verdadeira licença, e sim uma autorização administrativa.

Seria desnecessário discutir a denominação do ato administrativo correspondente. Vale mais enfatizar que a avaliação da legalidade de se autorizar o uso do fogo em atividades agropastoris ou florestais na Amazônia trata de sindicar o ato administrativo, e não pôr em dúvida a constitucionalidade em tese do texto legal. Atualmente, na Amazônia, se alega que peculiaridades locais ou regionais não mais justificam a autorização pelo Poder Público do emprego do fogo em práticas econômicas agropastoris ou florestais.

Esse exame não precisa e nem pode ficar atrelado à velha distinção mecânica entre ato discricionário e ato vinculado, pois importa mais decidir, com base em argumentos jurídicos substantivos, se o direito, bem interpretado, ainda permite ou passou a refutar o emprego do fogo em atividades agropastoris ou florestais, dadas as peculiaridades locais ou regionais contemporâneas.

Se o direito, corretamente interpretado, exige a cessação do uso do fogo em práticas agropastoris ou florestais, em face das peculiaridades locais ou regionais, então o juízo que se realiza é o da legalidade, não a intromissão no que se costuma chamar de "mérito administrativo". No entanto, a ausência de ataque à constitucionalidade do dispositivo legal não impede o uso de argumentos constitucionais para a sindicância da atividade administrativa de autorização do uso do fogo. O juízo de legalidade do ato administrativo envolve todo o sistema jurídico dotado de autoridade, e até com especial relevo, por razões óbvias aos especialistas, a Constituição.

Deveras, "não há discricionariedade do administrador frente aos direitos consagrados, quiçá constitucionalmente. Nesse campo, a atividade é vinculada sem admissão de qualquer exegese que vise afastar a garantia pétrea” da proteção jurídica e, inclusive, da 
proteção pela via judicial (STJ, REsp 575998/MG, Relator Ministro Luiz Fux, Primeira Turma, DJ de 16.11.2004, p. 191).

Já do ponto de vista doutrinário, a dicotomia discricionariedade/vinculação também se encontra fustigada por trabalhos que revelam o que realmente importa: a adequação da atividade administrativa à lei e à Constituição, em cada caso examinado, de acordo com razões suficientes.

No campo do direito ambiental, esse problema foi muito bem percebido pela doutrina (KRELL, 2008, 56/72) segundo a qual a natureza da licença ambiental (se licença mesmo ou autorização) pouco contribui para melhor concretização dos direitos das pessoas e para a abrangência do controle dos atos administrativos ambientais. A vinculação do conceito tradicional de licença à ideia de ato vinculado e do conceito tradicional de autorização à ideia de ato discricionário não pode ser feita de maneira antecipada, pois ela depende, acima de tudo, do teor da respectiva lei. De maneira esclarecedora Krell destaca que há, no Brasil, pouquíssimas leis ambientais que estabelecem as exigências materiais para a concessão de uma licença ambiental ou a sua obrigatória negação.

Se é inútil insistir indagando sobre a natureza da licença ambiental (até porque existem vários tipos diferentes de licença ambiental), a concessão de maior ou menor espaço para os órgãos administrativos nessa seara deve ser feita pelo legislador, mediante critérios de grau de afetação dos direitos fundamentais no caso concreto, bem como a análise do nível de periculosidade e nocividade social das atividades a serem licenciadas. A definição dos espaços pela própria lei tem o objetivo de não contrariar o princípio constitucional da reserva legal, além de viabilizar decisões administrativas racionais, razoáveis e controláveis (KRELL, 2008, 70).

No direito brasileiro, a maioria das leis parlamentares não assenta regras materiais sobre o licenciamento nas diferentes áreas setoriais da proteção ambiental, sendo esse o caso dos códigos florestais, antigo e novo, quanto ao uso do fogo em práticas agropastoris ou florestais. Isso, porém, não pode conduzir à conclusão equivocada das decisões materiais sobre os pressupostos de um licenciamento ambiental de consubstanciarem sempre "mérito administrativo" imune à sindicância acerca de sua legalidade. Importa examinar a exata compatibilidade da postura do Poder Público com a lei e com a Constituição. Distinções mecânicas e artificiais, feitas antecipadamente e que afastam o juízo das circunstâncias específicas de cada caso concreto podem acarretar violações graves à ordem jurídica.

O não estabelecimento na lei formal das regras materiais para a autorização do emprego do fogo em práticas agropastoris ou florestais, na verdade, torna mais suscetível ao exame a atividade administrativa correspondente. A latitude do espaço deixado pelo legislador ao administrador, para fixação das peculiaridades e circunstâncias que justificam a autorização do uso do fogo em práticas agropastoris ou florestais, aumenta consideravelmente a probabilidade de violação da garantia 
fundamental da lei formal para a criação originária de direitos e deveres $\left(\operatorname{art} .5^{\circ}\right.$, II, da Constituição da República).

Disso não decorre a declaração de inconstitucionalidade dos dispositivos legais, no entanto as diversas interpretações que podem ser feitas pelo Administrador tornam-se mais amplamente criticáveis, sob o pressuposto de que deveriam ter sido decididas pelo legislador. Em tais casos, o maior espaço de ação do Administrador não resulta, automaticamente, em maior imunidade deste, mas justamente no contrário, em face do direito de todos terem suas questões fundamentais resolvidas pela lei formal criada mediante o processo legislativo.

Considerando as circunstâncias descritas anteriormente, acerca das graves consequências acarretadas pelas queimadas e incêndios florestais ao ambiente e à saúde das pessoas, constitui uma questão fundamental decidir se as peculiaridades regionais ou locais ainda justificam o emprego do fogo em práticas agropastoris ou florestais na Amazônia, ou se estão a exigir sua integral e imediata proibição, na produção rurícola em geral, ainda que dita controlada. Como questão fundamental, isso só pode ser decidido à luz da melhor interpretação do que dizem a lei e a Constituição, e não apenas por razões de conveniência do Poder Público, do que resulta uma nítida necessidade de sindicar juridicamente a atividade administrativa de autorizar o emprego do fogo em atividades agropastoris ou florestais na Amazônia visando ao incremento da renda e ao desenvolvimento regional.

Para tal conclusão, relevante ainda o título Discricionariedade administrativa e o direito fundamental à boa administração pública, sob o qual o professor Juarez Freitas disserta sobre a sindicabilidade aprofundada dos atos administrativos, os vícios de arbitrariedade por excesso ou omissão, a era da motivação administrativa, a responsabilidade do Estado por ações e omissões, e os princípios da prevenção e da precaução (FREITAS, 2007). O professor defende a tese de que se faz cogente enfrentar toda e qualquer antijuridicidade das escolhas públicas (administrativas), para além de exame adstrito a aspectos meramente formais. Em outras palavras, a questão realmente essencial é escrutinar a atividade administrativa em face da lei e da Constituição, em cada caso examinado, de acordo com razões suficientes.

O emprego do fogo nas práticas agropastoris ou florestais na Amazônia, ao menos em regiões que exibem as circunstâncias deletérias já descritas, revela risco de dano potencial grave ao meio ambiente e à saúde das pessoas, porquanto a condição da vegetação dessas localidades, no período de estio, propicia a propagação descontrolada de incêndios, cujas consequências - abertura de clarões e acúmulo de materiais de fácil combustão (hulhas e outros materiais orgânicos em decomposição) - retroalimentam a difusão do fogo.

Trata-se de prática de exploração econômica de recursos naturais que oferece riscos de elevada magnitude ao meio ambiente e à integridade das pessoas. Os eventos ocorridos em 2005 no Acre e os estudos realizados a partir de então denotam que 
a prática é, efetivamente, nociva e exige, mormente ante a existência de métodos alternativos ao uso do fogo, sua supressão. Se o emprego legítimo do fogo na agricultura e na pecuária resta condicionado à existência de características próprias do local ou da região, então a reunião das circunstâncias preditas está a repelir a prática de queima e pousio, em vez de atraí-la.

Ora, (1) o emprego do fogo enseja uma extenuação do solo e, por conseguinte, estimula a pressão expansiva em novas áreas cultiváveis, com uma progressiva perda da vegetação nativa, cuja preservação colimou a lei florestal; (2) a vegetação na Amazônia é suscetível à alta propagação de focos de incêndio no período seco, época em que ocorrem as queimadas, indubitavelmente, inviabilizando seu controle, como disposto na lei florestal; (3) existem alternativas de substituição dessa prática por outros métodos que otimizam o aproveitamento do solo, consorciando o combate à utilização do fogo com a recuperação de áreas degradadas.

As peculiaridades regionais ou locais da Amazônia, portanto não apenas deixaram de justificar o emprego do fogo em práticas agropastoris ou florestais visando ao incremento da renda e ao desenvolvimento regional, como estão a exigir integral e imediata proibição às queimadas na produção rurícola em geral. Invoca-se, em casos assim, o princípio do gerenciamento dos riscos sistêmicos de danos graves, que prescreve a escolha de métodos que agreguem à exploração econômica de recursos naturais a redução dos conhecidos danos potenciais ao meio ambiente e a reparação progressiva dos já deflagrados pela atividade.

No âmbito do direito ambiental, quiçá, a concepção da justiça compensatória encontra seus limites, em especial em casos nos quais os conhecidos e pesados danos causados a um sem número de pessoas são de difícil reparação. Em tais circunstâncias, o que mais importa para o direito é evitar danos que são altamente prováveis e sistêmicos, como os descritos neste texto, em face de incêndios florestais decorrentes das queimadas de início autorizadas pelo Poder Público. Como a relação direta entre o causador dos danos e a parte lesada nem sempre está clara do ponto de vista da responsabilidade, a solução correta seria administrar riscos sociais em vez de ratificar direitos individuais (SUNSTEIN, 2009, 425). Graves danos já ocorreram e o risco de voltarem a acontecer não constitui mera suposição. A probabilidade de novas ocorrências (riscos de danos potenciais graves) é alta, se essa prática não for cessada.

Não há dúvida de que a regulação jurídica infraconstitucional da matéria ambiental e da saúde, juntamente com os preceitos constitucionais correspondentes, preveniria tais danos (para isso, basta ler os cinco primeiros artigos da Lei $\mathrm{n}$. 6.938/1981, e os três primeiros da Lei n. 8.080/1990). Essa situação materializa uma hipótese segundo a qual, “onde o Congresso não se expressou claramente, a sustentação (judicial) deveria também ser garantida, já que essa é a postura mais razoável de se atribuir a uma legislação à luz dos propósitos do programa regulatório em evidência, que são justamente reduzir os danos desse tipo” (SUNSTEIN, 2009, 438). 
Diante do não estabelecimento pela lei formal das regras materiais para a autorização do emprego do fogo em práticas agropastoris ou florestais visando ao incremente da renda e ao desenvolvimento regional, os danos regulatórios e os riscos de danos potenciais graves justificam a revisão da prática na Amazônia nas atuais circunstâncias.

\section{Constituição, economia e cultura das Queimadas}

A necessidade de reavaliar o uso do fogo em atividades econômicas agropastoris ou florestais na Amazônia também decorre do argumento constitucional. Como já foi dito, não é a lei em tese, o código florestal brasileiro, que precisa ser sindicada, mas a atividade da Administração de autorizar o uso do fogo em práticas agropastoris ou florestais visando ao aumento da renda e ao desenvolvimento regional, dadas as peculiaridades regionais de propagação de focos de incêndio.

No artigo 225, a Constituição da República garante o "direito ao meio ambiente ecologicamente equilibrado [como] bem de uso comum do povo e essencial à sadia qualidade de vida, impondo-se ao Poder Público e à coletividade defendê-lo e preservá-lo para as presentes e futuras gerações".

A atuação do Poder Público tendente à efetivação desse direito integra, dentre outros: (1) a exigência de um estudo prévio de impacto ambiental, para a instalação de atividade potencialmente causadora de significativa degradação ao meio ambiente; (2) o controle do emprego de técnicas ou métodos que ofereçam risco à vida, à qualidade de vida e ao meio ambiente; (3) a promoção de educação ambiental para a preservação desse último, determinando-se, ainda, que as atividades realizadas na Floresta Amazônica deverão ser feitas de forma a assegurar a preservação do meio ambiente (incisos IV, V, VI e $\S 4^{\circ}$, do mesmo art. 225, CRFB).

No âmbito da saúde, a Constituição a reconhece como direito de todos e dever do Estado. Diz também que o direito à saúde deve ser garantido mediante políticas sociais e econômicas que visem à redução do risco de doença e de outros agravos e ao acesso universal e igualitário às ações e serviços para sua promoção, proteção e recuperação (art. 196). No artigo 198, II, a Constituição prevê que o sistema único de saúde será organizado segundo a diretriz de atendimento integral, com prioridade para as atividades preventivas, sem prejuízo dos serviços assistenciais.

Dos dispositivos decorre o princípio da prevenção, para o direito administrativo e ambiental. A prevenção busca cuidar de riscos probabilísticos (risco de dano potencial), traduzindo a conduta racional ante um mal que a ciência pode objetivar e mensurar, ou seja, diante de um perigo certo e quando há elementos seguros para afirmar que determinada atividade é efetivamente perigosa. "Na prática, o princípio da prevenção tem por objeto impedir a ocorrência de danos ao meio ambiente, por meio da imposição de medidas ditas preventivas, antes da implantação de estabelecimentos e atividades considerados efetiva ou potencialmente poluidores" (SETZER \& GOUVEIA, 2008, 167). 
É bem a questão do uso do fogo em atividades econômicas agropastoris ou florestais na Amazônia, pois as evidências indicam com segurança que a queima e a excessiva antropização do meio rural, com a abertura de grandes clarões na floresta primitiva, têm propiciado uma expansão indiscriminada dos focos de calor, ocasionando grandes incêndios, e as consequências danosas ao ambiente e à saúde das pessoas já referidas.

$\mathrm{Na}$ aplicação judicial do princípio da prevenção, já se decidiu que o artigo 225 da Constituição da República instrumentaliza a exigência segundo a qual, "uma vez que se possa prever que uma atividade possa ser danosa, ela deve ser evitada, (...) exigindo-se, assim, na forma da lei, para instalação de obra ou atividade potencialmente causadora de significativa degradação do meio ambiente, estudo prévio de impacto ambiental” (TRF 1 a Região, AC 2007.01.00.006961-5/RR, Relator Desembargador Federal Souza Prudente, Sexta Turma; e-DJF1 de 27.4.2009, p.274).

Portanto, há argumentos de ordem constitucional para concluir pela rejeição do uso do fogo em atividades econômicas agropastoris ou florestais em regiões da Amazônia suscetíveis à alta propagação de focos de incêndio no período seco. A manutenção do bioma amazônico integra o patrimônio fundamental de todos os membros da comunidade jurídica jungida pela Constituição; e as atividades econômicas que importem em exploração dos recursos naturais devem satisfazer o anseio preservacionista, elegido como primaz pelo consenso fundador engendrado, em detrimento da exaustão dos recursos no imediatismo de uma irracional exploração.

Convém recordar que o emprego econômico do fogo na agricultura e pastagem resulta irracional, ante as variáveis expostas. Chega a ser prejudicial ao produtor rural (MOTTA E OUTROS, 2002), extenua a terra, empobrece o solo, limita o período de produtividade deste, e perpetua a monocultura temporária. Além disso, é nefasto às populações locais, que sofrem, durante o período seco devido à poluição atmosférica e ao acometimento de doenças respiratórias, o que resulta em mortes. Ainda, reduz a visibilidade, causa impactos severos ao meio ambiente, com a supressão da biodiversidade florística e faunística características da região, reduz o sequestro de carbono mas, em contrapartida, reforça a emissão desse mesmo poluente, e aumenta o risco de propagação de focos de incêndio. Nas circunstâncias descritas, o princípio constitucional da prevenção impõe ao Estado a obrigação de evitar danos graves e injustos, o dever de agir preventivamente, não sendo o caso invocar imunidade por razões de conveniência ou oportunidade (discricionariedade).

$\mathrm{Na}$ outra face, a utilização de métodos alternativos oferece especular um contraponto a todas as mazelas decorrentes do uso do fogo: incrementa a produção agrícola regional, promove reutilização de áreas degradadas, evita o esgotamento do solo, reduz o período de descanso da terra, diversifica os nutrientes do solo, mitiga a pressão por áreas ainda cobertas por vegetação primária, aumenta o potencial de absorção de gás carbônico, minimiza a emissão de poluentes à atmosfera, mantém o equilíbrio climático e edáfico. 
Com a aplicação dessas diretrizes, a esfera da dita discricionariedade administrativa fica submetida ao primado efetivo dos direitos fundamentais. E não há alternativa legítima. Para o professor Juarez Freitas,

(...) nas escolhas intertemporais, se se tratar de mal altamente provável e irreversível, avaliado com juízo de verossimilhança, a administração (ou quem faça as suas vezes) tem o dever de agir - quer dizer, tomar as medidas provisórias de precaução -, sob pena de responder pelos danos injustos, admitidas tão-só as excludentes. (FREITAS, 2007, 106).

Em circunstâncias como as descritas anteriormente, a ação ou a omissão dos agentes públicos acarreta até mesmo a responsabilização do Estado nos termos do artigo 37, § $6^{\circ}$, da Constituição.

Perpetuar o uso do fogo, nas atividades econômicas agropastoris ou florestais em regiões da Amazônia suscetíveis a alta propagação de focos de incêndio no período seco, é incompatível com a proteção constitucional ao meio ambiente. Colide frontalmente com o direito ao meio ambiente ecologicamente equilibrado, um bem essencial à saudável qualidade de vida, com o direito à saúde e com outros direitos e interesses fundamentais juridicamente resguardados. O emprego do fogo, nas circunstâncias regionais ou locais apresentadas, constitui prática que não se coaduna com direitos legais e constitucionais consagrados no sistema jurídico, a impor ao Estado sua supressão.

Eventualmente, há mesmo concordância a respeito desse juízo. A ausência de controvérsia sobre a necessidade de proscrever o uso do fogo na Floresta Amazônica como questão de justiça restou manifestada em audiência inicial realizada no âmbito da ação civil pública protagonizada pelo Ministério Público no Acre. Na ocasião, os dirigentes de entidades representativas dos trabalhadores rurais, tanto a Central Única dos Trabalhadores quanto a Federação dos Trabalhadores, revelaram estar de acordo com o objetivo de proscrição do uso do fogo na agricultura regional e o propósito mais geral da sustentabilidade ("usar o presente sem agredir o futuro"). ${ }^{7} \mathrm{O}$ juízo normativo, portanto, tem força racional, ainda que os atores de um conflito muitas vezes dissimulem suas convicções e prossigam na controvérsia.

\section{I A ECONOMIA DAS QUEIMAdAS E OS DiReIToS}

Os atores do conflito analisado não se dão por vencidos, mesmo concordando em público que a melhor interpretação da justiça legal exige a cessação da prática. Há dois questionamentos que atacam de maneira direta os argumentos de princípio que sustentam o juízo de ser juridicamente necessário suprimir o uso fogo em atividades econômicas agropastoris na Amazônia. Eles consubstanciam os temas da economia e da cultura, e são importantes do ponto de vista dos princípios, porque 
exibidos no nível constitucional para, em primeira linha, defender os interesses dos produtores rurais.

O argumento econômico prega que uma mudança técnica nas atividades econômicas agropastoris ou florestais constitui uma resposta dos agentes do mercado orientada para substituir recursos mais escassos ou custosos por outros mais abundantes e baratos. Por esse viés, os agricultores continuam a empregar o fogo como técnica de produção porque, atualmente, a combinação de fatores de produção que otimiza a renda agrícola inclui a queima. Os produtores agrícolas, portanto, deixariam de usar o fogo apenas quando uma nova combinação de fatores aumentasse a renda. A intervenção do direito não poderia ocorrer de imediato, e sim aguardar a nova combinação de fatores. Afinal, a Constituição protege a propriedade e a liberdade de iniciativa econômica.

Se o argumento econômico-tecnológico pretende ser decisivo, ao apregoar a espera indefinida para as alternativas às queimas se tornarem menos custosas, desprovido de outra consideração, ele apresenta um problema grave. A defesa pura e simples da eficiência econômica nesses termos pode justificar posições altamente questionáveis, quando não repudiadas publicamente por todos e vedadas pela Constituição.

Pela regra da eficiência do modelo, por exemplo, o Estado não poderia combater o trabalho análogo à condição de escravidão, prática que, segundo se noticia recorrentemente, ainda viceja na Amazônia e em centros urbanos industrializados. Certamente, a exploração da força do trabalhador submetido à condição análoga à de escravo tem menor custo para seu beneficiário (seja o empreendedor rural, na Amazônia, seja o proprietário da confecção que contrata imigrantes estrangeiros clandestinos, em algum prédio localizado em plena região central da metrópole urbana), se comparado àquele do empregado legalizado.

O problema com a aplicação irrefletida do princípio da eficiência, em questões políticas, pode conduzir à desconsideração, como o exemplo sugere, da inviolabilidade das pessoas, especialmente quando estas constituem minoria ou fazem parte de um grupo que, numericamente majoritário, encontre-se vulnerável e seja alvo de danos terríveis causados por prática julgada pelos agentes racionais do mercado como a mais eficiente do ponto de vista econômico. Aliás, este é bem o caso em região na qual todos estão, ano a ano, submetidos às graves consequências decorrentes das queimadas e dos incêndios.

A inviolabilidade da pessoa, a exigência de ser protegida sua integridade e seu bem-estar não podem ser sobrepujadas facilmente por um cálculo utilitário ou de maximização da atividade econômica. Todo argumento comprometido com o ideal de justiça do Estado Constitucional Democrático afirma o caráter peremptório dos direitos e a força derrogatória das considerações utilitárias, que podem implicar a violação da integridade das pessoas. Os direitos, afinal, são posições que valem contra a maioria. Os partidários dos direitos costumam afirmar que "indivíduos têm 
direitos. E há coisas que nenhuma pessoa ou grupo pode fazer com os indivíduos (sem lhes violar os direitos)" (NOZICK, 1991, 09). ${ }^{8}$ Ou que

(...) cada pessoa possui uma inviolabilidade fundada na justiça que nem mesmo o bem-estar da sociedade como um todo pode ignorar. (...) Portanto numa sociedade justa as liberdades da cidadania igual são consideradas invioláveis; os direitos assegurados pela justiça não estão sujeitos à negociação política ou ao cálculo de interesses sociais. (RAWLS, 1997, 04).

$\mathrm{Ou}$, ainda, que

(...) direitos são mais bem compreendidos como trunfos sobre alguma justificação de fundo para decisões políticas que afirma um objetivo para a comunidade como um todo (DWORKIN, 1984, 153). ${ }^{9}$

A intervenção jurídica no sistema econômico pode encontrar razões suficientes, e, quando as encontra, a intervenção há de ser feita, sob pena de grave injustiça. A defesa de que a economia é um reino imune a considerações jurídicas pode acarretar a violação de direitos. A história está repleta de exemplos. No direito constitucional norte-americano, é conhecida a decisão da Suprema Corte de anular, no início do século 20, leis que protegiam as mulheres, estabelecendo jornada máxima diária de trabalho. A Corte argumentou que não poderia haver legislação intervindo nas relações privadas de trabalho. Há profundo equívoco em considerar indevida a intervenção jurídica na economia, tida como uma esfera anterior ao Estado e à política, em que os agentes racionais do mercado são livres para perseguir seus objetivos de máximo proveito. A esfera da economia não é anterior ao Estado, mas sim resultado das escolhas feitas pela política e pelo direito.

Na verdade, na avaliação econômica, é necessário considerar o postulado da eficiência, e também a gravidade dos problemas resultantes da desigualdade e da liberdade, a exigir intervenção social e até custeio governamental. Não se deve apenas comprometer a eficiência, no entanto, a equidade tem seu papel. Por certo, há circunstâncias em que o limite para a base racional do mercado aparece de maneira inquestionável, como no caso dos bens públicos, assim bem a defesa, o policiamento e a proteção do meio ambiente. Os resultados de eficiência, sozinhos, não podem garantir a equidade distributiva, e seus abrangentes poderes "têm de ser suplementados com a criação de oportunidades sociais básicas para a equidade e a justiça social” (SEN, 2010, p. 190). É importante reconhecer a conexão da economia, e também do desenvolvimento, com a justiça social, aceitando que a abordagem das práticas econômicas é uma questão de valoração e julgamento, uma avaliação de políticas públicas. 
O domínio imperial do mercado deve ser desafiado, ainda que ele seja um bemsucedido mecanismo para organizar a produção e a distribuição de bens na sociedade, visando à afluência e à prosperidade. Uma economia de mercado não pode significar sem mais uma sociedade de mercado (SANDEL, 2012).

$\mathrm{Na}$ vida em sociedade, há outros valores que devem ser respeitados, e não apenas os do mercado. Exemplo: a integridade dos seres humanos e de outras espécies. Aguardar indefinidamente a realização de um incentivo econômico para a adoção de tecnologias alternativas ao uso do fogo na Amazônia é capitular frente aos imperativos do mercado, desprezando outros valores, como os recursos naturais, os ecossistemas e a saúde das pessoas. É necessário debater em que circunstâncias os mercados atendem ao bem público e quais aquelas em que eles são intrusos (SANDEL, 2012, 19). Essa é uma questão moral e política na qual o direito, especialmente o direito constitucional, tem um peso relevante.

Com base nos direitos das pessoas e na Constituição, o argumento da economia não pode ser aceito sem contestação. Os direitos assegurados pela justiça não estão sujeitos ao cálculo de interesses sociais ou do mercado. E se os produtores rurais levantarem a proteção constitucional da propriedade e da liberdade de iniciativa privada para a defesa da primazia do argumento econômico, cumpriria responder que a proteção não resta anulada com a proibição do uso do fogo nas atividades econômicas agropastoris e florestais. A propriedade permanece privada e a liberdade de iniciativa se mantém, ainda que se deva observar essa proibição específica. Está se ordenando apenas a propriedade e a liberdade, como é próprio de um regime constitucional de liberdades iguais. Não é o que acontece com os outros direitos em jogo, se for o caso de manter autorizado o uso indiscriminado do fogo nas atividades econômicas. Os danos descritos aqui retratam violações aos direitos fundamentais das pessoas - afetando profundamente sua integridade e a das outras espécies e os recursos naturais.

\subsection{A Cultura das Queimadas e a Constituição}

O argumento da cultura deve ser examinado em duas dimensões, considerando sua complexidade. A primeira é relativa às práticas do uso do fogo que visam ao incremento da renda e ao desenvolvimento regional e em que avulta o primado da exploração econômica dos recursos naturais. A segunda se refere ao uso do fogo nas práticas de agricultura de subsistência exercidas pelas populações tradicionais e indígenas. A avaliação crítica do texto se volta essencialmente contra a primeira. Mas nos dois casos, a base constitucional das alegações é suscitada pelos atores do conflito, especialmente pelo Estado, quando defende não ser legítimo cessar as autorizações para as "queimas controladas".

Começando pela primeira dimensão, que reivindica abrigo na Constituição, pois esta garante a todos o pleno exercício dos direitos culturais e estabelece que o 
patrimônio cultural brasileiro é constituído dos bens de natureza material e imaterial portadores de referência à identidade, à ação, à memória dos diferentes grupos formadores da sociedade brasileira, incluindo formas de expressão e os modos de criar, fazer e viver (arts. 215 e 216, I e II, Constituição de 1988). Dessa maneira, o emprego do fogo em atividades agropastoris ou florestas na região amazônica, mesmo na modalidade econômica visando à geração de renda e ao desenvolvimento regional, constituiria um modo de criar, fazer e viver protegido pela Constituição.

O ponto exige inicialmente uma resposta mais geral, para não se concluir de imediato que práticas culturais estão imunes à crítica. Devidamente examinada, a cultura não é um problema. Como esclarece Habermas, pessoas vivem em contextos partilhados de valor nos quais se formam e fornecem sentido a suas existências. Elas adquirem identidade na socialização e nas experiências intersubjetivas. Nesse sentido, o direito das pessoas aos contextos vitais de formação é garantido pela própria Constituição, desde que não violem direitos fundamentais de outros e não envolvam desigualdades profundas. Há aqui uma defesa de direitos individuais, inclusive quando se faz referência à cultura. A proteção legal desta tem lugar em função da integridade do indivíduo que formou sua identidade em determinado contexto de valores intersubjetivamente partilhados. Disso não decorre a excelência da cultura de origem ou a necessidade de sua preservação administrativa incondicional (HABERMAS, 2002, p. 251).

Em outras palavras, importa proteger os contextos culturais nos quais as pessoas se formam e constroem suas identidades, dando curso e encontrando sentido para suas vidas. A proteção jurídica, contudo, se dá em favor dos próprios indivíduos, e não à custa da sua integridade. Não pode haver garantias para as práticas que resultam injustificadamente em violações claras e graves de direitos básicos. Nas sociedades pluralistas dos Estados constitucionais democráticos que asseguram liberdades iguais, a única garantia possível e necessária é a liberdade dos integrantes de um grupo cultural de dizer sim ou não à prática repetida. Com tal garantia, os integrantes do grupo vão poder se manifestar, refletir, criticar e, se for o caso, até rever a prática que pretendem levar adiante. Com isso, respeita-se a integridade dos indivíduos, de dentro ou de fora do grupo, pois os direitos de todos são levados a sério.

Considerando essa perspectiva e recorrendo novamente ao contexto conflituoso reproduzido pela ação civil pública protagonizada pelo Ministério Público no Acre, é interessante observar que os produtores, representados por entidades sindicais em audiência judicial, não defenderam exatamente a continuidade do emprego do fogo nas práticas agropastoris ou florestais. Não houve uma defesa das queimadas como modo de produção de valor cultural inestimável. Na verdade, a preocupação maior dos representantes classistas foi a falta de acesso a alternativas técnicas decentes e eficazes para preparar a terra para o cultivo. Em nenhum momento a prática foi afirmada 
como elemento cultural constitutivo da identidade do produtor rural, nem se alegou que sua vedação agrediria um valor profundo da existência.

Ao se posicionarem na audiência, os representantes dos trabalhadores rurais reclamaram pois não teriam como produzir com a cessação imediata das autorizações para o emprego do fogo e a falta de disponibilização simultânea de mecanismos alternativos para preparação da terra. Esse argumento é, antes de tudo, de natureza socioeconômica, pois ele se volta não contra a agressão a uma característica fundamental que dá sentido à existência, mas contra a falta de alternativa viável e tempestiva para o método produtivo utilizado há bastante tempo. Assim, na primeira dimensão do argumento cultural, a vedação ao emprego do fogo não significa um menosprezo à autenticidade do indivíduo, se disponível meio alternativo capaz de suprir a prática proscrita. Nessa dimensão, a prática sempre foi considerada instrumental, e não valiosa por si mesma. Quanto ao argumento de que, por ser assim há muito tempo, deve perdurar, não se sustenta. Há um empecilho nos direitos.

Como desdobramento da primeira dimensão, há outra alegação, muito popular, segundo a qual não é possível mudar repentinamente uma prática cultural antiga "mediante decreto". Mas ela falha na saída, por estar baseada em um pressuposto equivocado: o de uma prática social naturalmente constituir-se ao longo do tempo à margem da intervenção do Estado. O pressuposto, como o da eficiência econômica, é o statu quo ser neutro em relação ao direito e à política, tendo sua origem no curso natural das coisas e sendo seu mundo o de sujeitos privados que buscam só satisfazer necessidades egoístas.

A alegação foi levantada pelo Estado, no caso da ação civil pública ajuizada pelo Ministério Público no Acre. Erroneamente, pois o uso do fogo como uma técnica produtiva já é resultado de política pública intencionalmente executada pelo Poder estatal. De acordo com a lei, ao Estado cabe emitir autorizações para os desmates mediante as queimas ditas controladas. Por isso, ao revés, tem o poder-dever de negar essas autorizações, quando injustificadas. O statu quo, portanto, não é politicamente neutro, mas fruto de uma atividade estatal deliberada de manter, desde há muito tempo, o mesmo tipo tecnologia de produção agrícola, altamente perigosa e danosa, em áreas florestais da Amazônia. Os impactos negativos já são produzidos pelo direito e pela política, não advindos do "estado da natureza" anterior e imemorial.

Ainda em 1901, ao dispor sobre como se faz um deserto, Os sertões relatam que o colonizador, desde o alvorecer do século 17, copiou o proceder dos silvícolas e

(...) atacou a fundo a terra, escarificando-a nas explorações a céu aberto; esterilizou-a com os lastros das grupiaras; feriu-a a pontaços de alvião; degradou-a corroendo-a com as águas selvagens das torrentes; e deixou, aqui, ali, em toda parte, para sempre estéreis, (...) derruídas... Ora, estas selvatiquezas atravessaram toda a nossa história. (CUNHA, 1984, 26). 
E depois de sugerir imaginar-se sobre os resultados de semelhante processo aplicado, sem variantes, no decorrer dos séculos, Euclides noticia que as cartas régias de 17 de março de 1796 nomearam um juiz conservador das matas. Por sua vez, a de 11 de junho de 1799 decretou que "se coíba a indiscreta e desordenada ambição dos habitantes (da Bahia e Pernambuco) que têm assolado a ferro e fogo preciosas matas (...) que tanto abundavam e já hoje ficam a distancias consideráveis etc.” (CUNHA, 1984, 27).

A regulação atualmente executada pelo Estado produz consequências nefastas, violando a lei e a Constituição, que garantem a todos o direito ao meio ambiente ecologicamente equilibrado, o direito à saúde e o direito à vida. O argumento da cultura não tem força de impedir a cessação da prática do uso do fogo que visa ao desenvolvimento econômico regional em que avulta o primado da exploração econômica dos recursos naturais.

A segunda dimensão do argumento cuida da exceção das práticas de agricultura de subsistência exercidas pelas populações tradicionais e indígenas, conforme estabelece o novo Código Florestal brasileiro, no artigo 38, § $2^{\circ}$. A exceção não constava expressamente na lei florestal anterior. Nessa dimensão não se fala do uso do fogo visando ao desenvolvimento econômico regional e do primado da exploração econômica de recursos naturais. Seja como for, o novo conceito legal traz uma conjugação de requisitos que, devidamente observados, delimitam com bastante precisão o alcance da exceção. A aplicação da exceção, por sinal, pode ser encaminhada a partir de outros elementos do sistema legal.

Por meio do Decreto Presidencial n. 6.040, de 7 de fevereiro de 2007, a Administração Federal instituiu a Política Nacional de Desenvolvimento Sustentável dos Povos e Comunidades Tradicionais. O referido Decreto definiu como povos e comunidades tradicionais

(...) grupos culturalmente diferenciados e que se reconhecem como tais, que possuem formas próprias de organização social, que ocupam e usam territórios e recursos naturais como condição para sua reprodução cultural, social, religiosa, ancestral e econômica, utilizando conhecimentos, inovações e práticas gerados e transmitidos pela tradição $\left(\operatorname{art.} 3^{\circ}, \mathrm{I}\right)$.

Decidiu, ainda, que os territórios tradicionais são os espaços necessários a reprodução cultural, social e econômica dos povos e comunidades tradicionais, sejam eles utilizados de forma permanente ou temporária.

A Política Nacional de Desenvolvimento Sustentável dos Povos e Comunidades Tradicionais, além de princípios diversos, estabelece objetivos específicos, dentre os quais: (1) garantir aos povos e comunidades tradicionais seus territórios, e acesso aos recursos naturais que tradicionalmente utilizam para sua reprodução física, cultural 
e econômica; (2) reconhecer, com celeridade, a autoidentificação dos povos e comunidades tradicionais, de modo que possam ter acesso pleno aos seus direitos civis individuais e coletivos; e (3) apoiar e garantir a inclusão produtiva com a promoção de tecnologias sustentáveis, respeitando o sistema de organização social dos povos e comunidades tradicionais, valorizando os recursos naturais locais e práticas, saberes e tecnologias tradicionais.

Os mecanismos da Política instituída incluem os Planos de Desenvolvimento Sustentável dos Povos e Comunidades Tradicionais, a serem estabelecidos com base em parâmetros ambientais, regionais, temáticos, étnico-socio-culturais e elaborados com a participação equitativa dos representantes de órgãos governamentais e dos povos e comunidades tradicionais envolvidos.

Se a exceção permitindo o uso do fogo na agricultura de subsistência de populações tradicionais e indígenas for integrada à Política Nacional de Desenvolvimento Sustentável dos Povos e Comunidades Tradicionais, respeitando os conceitos, princípios, objetivos e mecanismos, ela estará observando o direito dos indivíduos de dar continuidade ao seu universo cultural de origem, dentro de um processo de redução e afastamento dos impactos negativos, pois o alcance da prática fica circunscrito aos casos controlados do uso do fogo na agricultura de subsistência de populações tradicionais e indígenas, no bojo de uma política compartilhada de desenvolvimento sustentável.

No final das contas, a nova lei ordena exigências constitucionais concorrentes, consistentes na salvaguarda dos modos de criar, fazer e viver (art. 216, II), na valorização da diversidade étnica e regional (art. 215, $\S 3^{\circ}, \mathrm{V}$ ), no reconhecimento aos índios de sua organização social, costumes e tradições (art. 231), mas igualmente na garantia dos direitos ao meio ambiente ecologicamente equilibrado (arts. 176, VI, e 225), à saúde (art. 196), à dignidade (art. $1^{\circ}$, III), e à vida (art. $5^{\circ}$ ). E assim pode extrair sua validade do sistema constitucional que protege as culturas e também as liberdades iguais de todos, incluindo o direito ao meio ambiente e o direito à saúde.

Como a sociedade pluralista instituída pela Constituição proíbe o privilégio de uma forma de vida em detrimento de outra, exigindo a coexistência equitativa, então se requer a ordenação dos direitos concorrentes em um dado contexto problemático. O ponto decisivo é a política compartilhada de desenvolvimento sustentável propiciar a revisão da prática sem imposição a partir de fora, mas por meio da reflexão autônoma dos integrantes das populações, assegurada pelos direitos de que são titulares.

\section{CONSIDERAÇÕES FINAIS}

O conflito socioambiental acarretado pelo uso do fogo em atividades econômicas agropastoris ou florestas na Amazônia é complexo, com diversas variáveis que se entrecruzam, de ordem histórica, ambiental, econômica, política, cultural, sem 
prejuízo de outras óticas. São vários os atores envolvidos diretamente no conflito, pois o interesse na sua resolução é difuso, em virtude de os impactos negativos causados pelas queimadas e incêndios atingirem todas as pessoas da sociedade. Não há grupos a salvo dos efeitos deletérios da fumaça e da degradação do ambiente natural, afetados que são os indivíduos na sua integridade. O conflito tem de ser avaliado do ponto de vista do direito, pois os interesses dos envolvidos também são formulados na forma de pretensões de tutela jurídica, e o sistema legal é o meio de resolução pacífica de disputas, nos marcos do Estado constitucional democrático que fundamenta o poder legítimo. A experiência externada na ação civil pública protagonizada pelo Ministério Público no Acre, destinada a impedir o uso do fogo como uma prática agropastoril, comprova essa necessidade.

Pelo cenário adverso de riscos de danos potenciais graves, se não cessada a prática da qual se originam há uma alta probabilidade de os impactos severos se repetirem ano a ano. Tendo em conta a legislação, deve ser proibido o uso do fogo em atividades agropastoris ou florestais. A resposta completa à questão que guiou a discussão preceitua que, considerando a ocorrência de acidentes graves (incêndios florestais descontrolados e de grandes proporções), os dados oficiais de pesados danos à economia, ao meio ambiente e à saúde das pessoas, inclusive registro de mortes, e sendo conhecido o alto risco de reincidência das consequências, então, de acordo com a lei e a Constituição, não é mais permitido o emprego do fogo em atividades econômicas agropastoris ou florestais na Amazônia.

Os interesses da economia de mercado não podem sobrepujar essa conclusão. Os direitos devem prevalecer frente a considerações utilitárias, no contexto problemático analisado. Ademais, as queimas e os incêndios provocados pela perda de controle apresentam custos consideráveis para a sociedade, chamada a custear a reparação dos prejuízos por meio dos tributos. Além de ter seus direitos afetados de maneira severa, do cidadão é exigido a contribuição para restauração dos bens públicos atingidos. Por esse viés, a injustiça é dupla, motivando a intervenção do direito para eliminá-la.

Os desafios postos pela cultura são ainda mais complexos. Os resultados alcançados são divididos em duas dimensões. Na primeira, discutindo-se o uso do fogo em atividades agropastoris visando à geração de renda e ao desenvolvimento regional, nas quais avulta o primado da exploração econômica de recursos naturais, não há razão jurídica suficiente para sua permanência. O caso que ilustrou a análise demonstra que, nessa dimensão, a prática não tem valor fundamental para quem a ela adere. Aqui, seu valor é instrumental, substituível por outro proceder, tornado-se disponível. Importa para o produtor rural inserido no mercado a produtividade, não só a subsistência. Para ele, se uma técnica agropastoril apresentar os mesmos ou melhores resultados, não há problema em substituir a utilizada. Como o fogo acarreta custos, então pode haver até mesmo um incentivo para a adoção de tecnologias alternativas conjugado à proibição legal do uso do fogo. 
A segunda dimensão da cultura trata das práticas de agricultura de subsistência exercidas pelas populações tradicionais e indígenas. Neste caso, a própria lei excepciona a proibição do uso do fogo, ainda que o faça fixando critérios para a ordenação dos direitos concorrentes. E o faz corretamente. A inserção da excepcionalidade na Política Nacional de Desenvolvimento Sustentável, se bem conduzida, pode permitir o respeito à diferença étnica e cultural e, simultaneamente, garantir a proteção das pessoas que sofrem os impactos negativos da prática generalizada e consentida do uso do fogo como técnica econômica de produção agropastoril. Pela exceção, a finalidade não é a produção para inserção no mercado de bens, mas para a subsistência de populações tradicionais e indígenas.

Uma prova de que as práticas de agricultura de subsistência exercidas pelas populações tradicionais e indígenas não preocupam tanto é o fato de a ação civil pública promovida pelo Ministério Público no Acre não ter se voltado contra tais populações. Apesar de haver arrolado no polo passivo, as instituições públicas de defesa do meio ambiente, além das esferas de governo, não consta como ré a Fundação Nacional do Índio ou qualquer outra associação silvícola ou tradicional. Por isso, a decisão a ser fixada no processo, sendo proibitiva do uso do fogo, não afetará as populações tradicionais e indígenas.

Assim circunscrita, a exceção não suspende o juízo de ser legalmente necessário suprimir o uso do fogo na Amazônia nas práticas agropastoris que visam ao incremento de renda e ao desenvolvimento regional, em que avulta o primado da exploração econômica dos recursos naturais. Os argumentos de princípios jurídicos exigem a cessação das queimadas como técnica de produção econômica na Amazônia. Este é o caminho para um desenvolvimento regional que leva em conta as exigências do direito e da sustentabilidade, e o modo correto de tratar o conflito em tela, à luz dos direitos.

: ARTIGO APROVADO (02/12/2012) : RECEBIDO EM 31/07/2012

NOTAS

1 BRASIL. Justiça Federal da $1^{\text {a }}$ Região. $1^{\text {a }}$ Vara da Seção Judiciária do Acre. Processo n. 2009.30.00.001438-4.

2 BRASIL. Justiça Federal da $1^{\text {a }}$ Região. $1^{\text {a }}$ Vara da Seção Judiciária do Acre. Processo n. 2009.30.00.001438-4. Memorando n. 03/DITEC/IBAMA/AC, de 20.04.2009, constando à fl. 259 dos autos do processo. 
3 BRASIL. Justiça Federal da $1^{a}$ Região. $1^{a}$ Vara da Seção Judiciária do Acre. Processo n. 2009.30.00.0014384. Entrevista concedida por pesquisador do INPA e do Parque Zoobotânico da Universidade Federal do Acre, Evandro Ferreira, Ph.D. em Botânica Sistemática pela City University of New York \& The New York Botanical Garden (NYBG), veiculada na rede mundial de computadores, em 25.08.2008, tendo sido juntada uma via impressa em papel ao volume VIII, fls. 364/7, apenso, dos autos do processo. Disponível em <http://terramagazine.terra.com.br/ blogdaamazonia/blog/2008/08/25/botanico-encontra-no-acre-formacao-vegetal-ainda-desconhecida-pela-ciencia/>. Acesso em: 24.11.2012.

4 BRASIL. Justiça Federal da $1^{\text {a }}$ Região. $1^{\text {a }}$ Vara da Seção Judiciária do Acre. Processo n. 2009.30.00.001438-4. Relatório de avaliação de danos elaborado pela Defesa Civil e juntado aos autos do processo.

5 Página 20 (As queimadas de 2005 e seu impacto nas florestas do Acre), 11.01.2006.

6 A lixiviação é um processo físico (o contato direto das precipitações pluviais com a superfície do solo, p.ex.) que conduz os nutrientes do solo a camadas mais profundas, as quais os sistemas radiculares desenvolvidos pelas plantas não têm acesso, tornando-o estéril.

7 BRASIL. Justiça Federal da $1^{\text {a }}$ Região. $1^{\text {a }}$ Vara da Seção Judiciária do Acre. Processo n. 2009.30.00.001438-4. A audiência foi uma tentativa do juízo da $1^{a}$ Vara Federal do Acre de conduzir as partes à conciliação, contando com a presença dos mais diversos setores da sociedade civil e do Poder Público, inclusive sindicatos de produtores rurais e prefeituras. A audiência foi registrada em meio audiovisual, e a cópia se encontra encartada aos autos do processo.

8 É sempre grande a possibilidade de crítica, quando se cita Nozick dessa maneira. Há o receio de que se referir assim a Nozikc implica adotar toda a sua teoria dos direitos. Aqui, não se faz a citação com esse propósito. A referência serve apenas para destacar que as teorias dos direitos, inclusive a teoria de Nozick, que defendem o caráter peremptório de tais razões, sua força conclusiva no argumento jurídico e político. Não se endossa com isso a própria visão de Nozick sobre quais são os direitos das pessoas. Afinal, a questão sobre o que são direitos é diferente daquela sobre quais são os direitos.

9 No original: "rights are best understood as trumps over some background justification for political decisions that states a goal for the community as a whole".

\section{REFERÊNCIAS BIBLIOGRÁFICAS}

BRASIL. Constituição da República Federativa do Brasil, de 5 de outubro de 1988, DOU,5.10.1988.

BRASIL. Decreto 2.661, de 8 de julho de 1998. Regulamenta o $§$ único do art. 27 da Lei 4.771, de 15 de setembro de 1965 (Código Florestal), mediante o estabelecimento de normas de precaução relativas ao emprego do fogo em práticas agropastoris e florestais, e dá outras providências, DOU,9.7.1998.

BRASIL. Decreto 6.040, de 7 de fevereiro de 2007. Institui a Política Nacional de Desenvolvimento Sustentável dos Povos e Comunidades Tradicionais, DOU, 8.2.2007.

BRASIL. Justiça Federal da $1^{\text {a }}$ Região. $1^{\text {a }}$ Vara da Seção Judiciária do Acre. Processo n. 2009.30.00.001438-4. BRASIL. Lei 4.771, de 15 de setembro de 1965. Institui o novo Código Florestal, DOU, 16.9.1965. Revogado pela Lei 12.651 , de 2012 .

BRASIL. Lei 12.651, de 25 de maio de 2012. Dispõe sobre a proteção da vegetação nativa; altera as leis 6.938, de 31 de agosto de 1981, 9.393, de 19 de dezembro de 1996, e 11.428, de 22 de dezembro de 2006; revoga as Leis 4.771, de 15 de setembro de 1965, e 7.754, de 14 de abril de 1989, e a Medida Provisória n. 2.166-67, de 24 de agosto de 2001; e dá outras providências, DOU, 28.5.2012.

BRASIL. Superior Tribunal de Justiça. REsp 575998/MG, Relator Ministro Luiz Fux, Primeira Turma, DJ, 16.11.2004, p. 191.

BRASIL. Tribunal Regional Federal (1 ${ }^{a}$ Região). Apelação Cível n. 2007.01.00.006961-5/RR, relator desembargador federal Souza Prudente, 6 Turma; e-DJF1, 27.4.2009, p. 274.

BROWN, Irving Foster; VASCONCELOS, Sumaia Saldanha de. As queimadas de 2005 e seu impacto nas florestas do Acre. Página 20, Rio Branco, 11.01.2006.

CUNHA, Euclides da. Os sertões. São Paulo: Três, 1984 (Biblioteca do Estudante). 
DWORKIN, Ronald. Rights as trumps. In: Jeremy Waldron. (Ed.). Theories of rights. Oxford: Oxford University Press, 1984.

FERREIRA, Evandro. Entrevista sobre formação vegetal no Acre ainda desconhecida pela ciência. Disponível em: $<$ http://terramagazine.terra.com.br/blogdaamazonia/blog/2008/08/25/botanico-encontra-no-acre-formacao-vegetalainda-desconhecida-pela-ciencia/>. Acesso em: 24 nov. 2012.

FREITAS, Juarez. Discricionariedade administrativa e o direito fundamental à boa administração pública. São Paulo: Malheiros, 2007.

HABERMAS, Jürgen. A inclusão do outro: estudos de teoria política. Trad. por George Sperber e Paulo Astor Soethe. São Paulo: Edições Loyola, 2002.

KRELL, Andreas J. Licença ou autorização ambiental? Revista de Direito Ambiental, ano 13, n. 49, p. 56-72, jan./mar. $/ 2008$.

LITTLE, Paul E. Os conflitos socioambientais: um campo de estudo e de ação política. In: Marcel Bursztyn. (Org.). A difícil sustentabilidade: política energética e conflitos ambientais. Rio de Janeiro: Garamond, 2001, p. $107-122$.

MESQUITA, Antônio Gilson Gomes. Impactos das queimadas sobre o ambiente e a biodiversidade acreana. Mimeo, s. d. MIRANDA, Evaristo Eduardo de; MORAES, Adriana Vieira de Camargo de; OSHIRO, Osvaldo Tadatomo. Comunicado Técnico, 18: queimadas na Amazônia brasileira em 2005. Campinas: Empresa Brasileira de Pesquisa Agropecuária, 2006.

MOTTA, Ronaldo Seroa da; MENDONÇA, Mário Jorge Cardoso; NEPSTAD, Daniel; VERA DIAZ, Maria del Carmen; ALENCAR, Ane; GOMES, João Carlos; ORTIZ, Ramon Arigoni. Texto para discussão n. 912: o custo econômico do fogo na Amazônia. Rio de Janeiro: Instituto de Pesquisa Econômica Aplicada, outubro de 2002. NOZICK, Robert. Anarquia, estado e utopia. Trad. por Ruy Jungmann. Rio de Janeiro: Jorge Zahar, 1991. RAWLS, John. Uma teoria da justiça. Trad. por Almiro Pisetta e Lenita M. R. Esteves. São Paulo: Martins Fontes, 1997.

SANDEL, Michael J. O que o dinheiro não compra: os limites morais do mercado. Trad. por Clóvis Marques. Rio de Janeiro: Civilização Brasileira, 2012.

SCHMITZ, Heribert. A transição da agricultura itinerante na Amazônia para novos sistemas. Revista Brasileira de Agroecologia, v. 2, n. 1, fev. 2007.

SEN, Amartya. Desenvolvimento como liberdade. Trad. por Laura Teixeira Motta. Revisão técnica de Ricardo Doninelli Mendes. São Paulo: Companhia das Letras, 2010.

SETZER, Joana; GOUVEIA, Nelson da Cruz. Princípio da precaução rima com ação. Revista de Direito Ambiental, ano 13, n. 49 , jan./mar. 2008.

SUNSTEIN, Cass R. A constituição parcial. Trad. por Manassés Teixeira Martins e Rafael Triginelli. Belo Horizonte: Del Rey, 2009.

\section{David Wilson de Abreu Pardo}

SQN 112, Bloco G, ap. 208 Asa Norte, 70762-070 Brasília - DF - Brasil davidpardolauol.com.br
Pós-doutorando no Centro de Desenvolvimento SUSTENTÁVEL DA UNIVERSIDADE DE BRASílIA Doutor e MESTRE EM DiREITO PELA Universidade FEDERAL de Santa Catarina

Professor ADJUNTO (AFASTADO) DA UnIVERsidadE FEDERAL DO ACRE 